\title{
TATA-BOX: A Model for Participatory Processes?
}

\author{
Sylvie Lardon
}

\begin{abstract}
Is TATA-BOX a model worth following, an example or a reference to use in designing other participatory processes or devices? To answer to this question, I went through the book to see if I could find the three main properties of participatory processes: the expression of viewpoints; the justification of reasoning; and the creation of new development models for territories. Three frameworks of analysis collectively guided my viewpoint in this critical analysis: the mechanisms of the construction of a participatory process; the potential of territorial governance; and the connection between collective and territorial actions. The first section discusses representation tools seen as intermediary objects between researchers and actors in co-construction devices. The second section successively considers participation, governance, and collective action as three facets for elucidating the process. The last section answers the crucial question: is TATA-BOX a model worth following? Hybridisation, integration, and inter-territorialisation are conditions for inventing the territories of the future (This is the title of the research project PSDR INVENTER (https://www.psdr4-auvergne.fr/PSDR-4/Les-4-projets/INVENTER), which aims at formalising the evolving dynamics of rural and metropolitan territories, drawing and designing the support for food governance changes.) and for managing territorial transitions.
\end{abstract}

\section{Foreword}

When people hear about the TATA-BOX project, they are immediately impressed. It sounds good. Pleasant and even friendly images come to mind. Why?

When you look at the outputs of the TATA-BOX process - its comic strip (Audouin et al. 2018b), the small, fully-illustrated support guide (Audouin et al. 2018a) -, its magic is still at work. Is this owing to the appealing look of the colourful diagrams presenting the complexity of the territorial transition process?

\footnotetext{
S. Lardon $(\bowtie)$

Territoires, Université Clermont Auvergne, AgroParisTech, INRA, Irstea, VetAgro Sup, Aubière, France

e-mail: sylvie.lardon@agroparistech.fr
} 
So, when the TATA-BOX authors ask you to do a critical analysis of their complete work, it's impossible to resist the desire to dive into the manuscript.

The design of the process was collective, along with the wish to review it, but the time allotted made that impossible. I therefore took up my pen of my own accord, although from the angle of a few collective viewpoints stated within the UMR Territoires in Clermont-Ferrand, ${ }^{1}$ with the intention of asking a few interdisciplinary questions on the work.

I do not claim to have been exhaustive in my statements, nor even to have fully examined the main question: is TATA-BOX a model worth following? At least not blindly like a cooking recipe (although cooks are also creative), but as an example or a reference to use in designing other participatory processes or devices.

To do so, I went through the book to see if I could find the three main properties that I attribute to participatory processes (Lardon 2013): the expression of viewpoints; the justification of reasoning; and the creation of new development models for territories.

I paid particular attention to the representations present in the book, whether systemic representations (Lemoigne 1990) presenting the complexity of the situation studied; spatial representations (Brunet 1986) anchoring processes in the territory; or simply representation models for an enhanced experience of the world (Legay 1986).

Three analysis frameworks collectively guided my viewpoint in this critical analysis. That of Gouttenoire et al. (2014) analyses the mechanisms of the construction of a participatory process. That of Lardon et al. (2014) raises questions around the potential of territorial governance. That of Amblard et al. (2018) connects collective and territorial action.

My paper consists of three sections. The first section discusses representation tools seen as intermediary objects (in the sense of Vinck 2009) between researchers and actors in co-construction devices. The second section successively addresses participation, governance, and collective action as three facets for elucidating the process. The last section answers the crucial question: is TATA-BOX a model worth following?

\section{From One Representation to the Other}

By now, you will have understood that I will not be discussing agroecology, the transition, or rural territories, to paraphrase the subtitle "Agroecological transitions: from theory to practice in local participatory design", but rather their representations in the book to see if the toolbox is effective.

\footnotetext{
${ }^{1}$ The UMR Territoires is a multidisciplinary body that associates humanities and social science researchers (geography, economics, management science, political science) with biotechnical science researchers (agronomics, systemic zootechnics). It carries out research on livestock farming models, rural and peri-urban territorial dynamics, collective coordination of actors, whether public or private, and support for change in territories.
} 
The first two representations provide the example to be followed. They are taken from Duru et al. (2015).

TATA-BOX is a complex, three-dimensional system. Natural resources, farming systems, and supply chains are the three corners of the triangle. The perspective is based on the formal and informal behaviours of the system of actors.

TATA-BOX is a part of a complex methodological itinerary, in the form of a loop, from analysis of the system to governance mechanisms, through design and prospective analysis.

Diagrams provide a model for clarification to convey equally complex thoughts. We let ourselves be guided along the path and plunge into the viewpoint. This is true for myself as a reader, but is it true for the authors of other chapters? Not all people share the same synthetic and systemic viewpoint.

\section{The Conceptual Framework(s)}

"Territorial Agroecological Transition at a concept crossroads" is the first section of the book. It is less ambitious in its representation methods than these first two diagrams, even if its contents are more ambitious.

Various representation methods support the announcement of the conceptual frameworks of the first section:

Special mention goes to the location maps of the actors involved in the processes (cf. chapter "An Integrated Approach to Livestock Farming Systems' Autonomy in Designing and Managing Agroecological Transition at the Farm and Territorial Levels") and to positioning the farmers interviewed along dual gradients of farming and commercialisation practices (cf. chapter "The Key Role of Actors in the Agroecological Transition of Farmers: A Case-Study in the TarnAveyron Basin").

Tables cross-reference the common worlds from Thévenot et al. (2000)'s economies of worth (cf. chapter "Socio-economic Characterisation of Agriculture Models"). This analysis can focus on levers for action (Thénard et al. 2014) based on livestock farming and feeding practices (cf. chapter "An Integrated Approach to Livestock Farming Systems' Autonomy in Designing and Managing Agroecological Transition at the Farm and Territorial Levels").

Spider graphs reveal the compromises, performances, and complementarities (cf. chapter “An Integrated Approach to Livestock Farming Systems' Autonomy in Designing and Managing Agroecological Transition at the Farm and Territorial Levels").

Typologies of farming methods (Therond et al. 2017) are projected around two pillars - from the global to the local, and from inputs to ecosystem services - and are described in terms of contemporary farming methods in Western countries (cf. chapter "Socio-economic Characterisation of Agriculture Models"). The two pillars of private/public goods and the short-term/long-term reveal the diversity of coordination methods (cf. chapter "Towards an Integrated Framework for the Governance 
of a Territorialised Agroecological Transition"). The analysis of the role of actors shows that their involvement in the agroecological transition (AET) is inversely proportional to the degree of their influence on farmers (cf. chapter "The Key Role of Actors in the Agroecological Transition of Farmers: A Case-Study in the TarnAveyron Basin").

System diagrams present the conceptual framework for analysing the autonomy of farming systems (Madelrieux et al. 2017) from three angles: the embeddedness of farms, their dependency and their footprints (cf. chapter "An Integrated Approach to Livestock Farming Systems' Autonomy in Designing and Managing Agroecological Transition at the Farm and Territorial Levels"). Others present the MLP approach to transitions (Geels 2004) and an alternative approach consisting in aligning pathways with the socio-technical regime (Elzen et al. 2004) (cf. chapter "Agroecological Transition from Farms to Territorialised Agri-Food Systems: Issues and Drivers"). Others establish the interrelation between the socio-technical system and the socio-ecological system, and their interactions with public policies (cf. chapter "Agroecological Transition from Farms to Territorialised Agri-Food Systems: Issues and Drivers").

Cognitive maps were created alongside farmers (cf. chapter "An Integrated Approach to Livestock Farming Systems' Autonomy in Designing and Managing Agroecological Transition at the Farm and Territorial Levels").

Pathways illustrated by the points of view of the interviewees (according to Coquil et al. 2013) present farmers' decisions to engage in the AET (cf. chapter "The Key Role of Actors in the Agroecological Transition of Farmers: A CaseStudy in the Tarn-Aveyron Basin").

Exchange networks between farmers and other actors show evolution in the establishment of coherence between innovation logics (cf. chapter "The Key Role of Actors in the Agroecological Transition of Farmers: A Case-Study in the TarnAveyron Basin").

Lastly, systems of relations between the farmers interviewed and the other actors met, depending on whether they are central or outlying actors, explain farmers' degrees of engagement in agroecology (cf. chapter "The Key Role of Actors in the Agroecological Transition of Farmers: A Case-Study in the Tarn-Aveyron Basin").

A box explains the learning dynamic of students involved in analysing strategies and actors' games (cf. chapter "The Key Role of Actors in the Agroecological Transition of Farmers: A Case-Study in the Tarn-Aveyron Basin").

By contrast, the plurality of viewpoints among researchers around the uncertainties of the AET (cf. chapter "A Plurality of Viewpoints Regarding the Uncertainties of the Agroecological Transition") is not represented.

As a result, several types of illustration support the researchers' reasoning. First, there are the classic representations presenting scientific results: tables, typologies based on pillars, radars, etc. Then there are the systemic diagrams that can be expected in a book of this type. Lastly, there is a set of innovative representations (pathways, relationships) that go even further, presenting both the results from the field, including verbatim quotes from actors, and interpretations seen from the angle of theoretical frameworks, so as to understand actors' games and their contribution to change decisions. 


\section{The Design Methodology}

Unsurprisingly, the second section of the book, "Support methodology for territorial agroecological transition design and feedback from the TATA-BOX project experience", presents a plethora of representations that are each as valuable and explicit as the next.

The participatory methodology (cf. chapter "Participatory Methodology for Designing an Agroecological Transition at Local Level") goes over the principles underpinning the construction of TATA-BOX (3-D diagram and round-trip pathway), before positioning farming types in Midi-Pyrénées (map), locating actors in the dialogue on local AET (diagram), and undertaking to analyse all work sessions between researchers, between stakeholders, and at the interface of the TATA-BOX process from 2014 to 2018 . A diagram of the actors' interaction strategies throughout the participatory process, along with photos of mind maps produced during sessions, the construction of playing cards to detail the transition pathway, the global cognitive map, summaries of the productions of the process, action plans, and so on, all constitute varied illustrations of the design and redesign of an interactive and didactic process. It is valid to say that the process generated multiple outputs.

In its own way, the reflexive analysis (cf. chapter "Towards a Reflective Approach to Research Project Management") illustrates the reflexive interventions throughout the process, as well as the participatory exercises highlighting the separate stages of constructing a common world, of project management, feedback and debriefing, and so on. It describes the scales of reflexivity and the levels of resistance to a new proposal. Its results are varied, from the representation of the roles imagined by the participants, to the evolution of participants' postures. It can be said that the actors were really engaged in the process.

The evaluation of the operationality of the process (cf. chapter "Evaluation of the Operationalisation of the TATA-BOX Process") draws from the classic canons of both quantitative analysis (staff tables, spider graphs, bar charts) and qualitative analysis (direct citations). It could be completed by a more detailed description of exchanges in order to qualify the collective dimension of the design work. Unsurprisingly, the actors recognise the proliferation of shared information and the positive consequences for individuals (acknowledgement of their capabilities?) but find the ideas to be unoriginal and their implementation to be difficult, for reasons related to funding and human resources. This is often the case in participatory processes, in which participants tend to highlight the utility of the dialogue as opposed to the originality of actions.

The present study, based on participants' discourses, will be completed by a direct analysis of the exchanges carried out during workshops. This should lead to a more detailed characterisation of exchanges, allowing to better qualify the collective dimension of the design work backed by the TATA-BOX process.

Elements to improve participants' representativeness, such as mobilising relays, organising shorter and more numerous meetings, and insertion within existing processes, should be explored in more detail. Those intended at improving creativity 
and reducing tension between innovation and realism may include the establishment of common ground upstream, understanding of the logics underpinning the different viewpoints, and potentially the diversification of participants' profiles. The fact remains that "the exercise of defining the path may have been carried out more to detect the favourable conditions as a whole than to select the means that will effectively have to be activated". TATA-BOX was clearly a design device that should be applied to use (Béguin and Rabardel 2000).

The idea of coexistence, in the field, of agricultural development models and agroecology is outlined, but not developed.

\section{Viewpoints}

Finally, a note on Information and Communication Technologies, which are supposed to help in the application of agroecological principles. They are considered to be "a range of tools for different agriculture models" (Therond et al. 2017). The proposed design process platform is open and modulable. It is organised around the concept of items, which can be constructed on the basis of an objective (from a document) or subjective (a viewpoint) piece of data that is characterised (attributes) and elucidated (topic) iteratively. Items are recorded and tagged by participants. This "item-based modelling method" is collaborative, around "topic maps" to make the diversity of viewpoints visible and palpable. It is designed to support the implementation of the transition following the design phase, by increasing the communication of information, using functional tools, managing knowledge, and offering decision aid tools. Yet, is there not a contradiction between the intensive use of new technologies (that consume a great deal of energy) and the paradigm of agroecology, which aims at consuming less fossil fuel? This is a dilemma facing the authors.

This perspective remains open for the most part, as the demonstration of its use has not been carried out around TATA-BOX itself.

\section{Cross-Analysis}

What can another group of researchers ${ }^{2}$ involved in other processes and other devices have to say about the TATA-BOX process and its analysis by the researchers involved in this participatory process? Let's go over a few collective analysis frameworks for participation, governance, and collective action stemming from the UMR Territoires in order to provide a more interdisciplinary analysis of the book.

\footnotetext{
${ }^{2}$ The UMR Territoires' AVEC Collective focuses on support in the territorial change process. Participants are involved in supporting actors through participatory devices, action research (and/ or training), support for reflexivity... and/or analysing these devices. Theoretical framing, exchanges, and the collective production of knowledge on support are at the heart of the scientific facilitation process.
} 


\section{The Key Points of a Participatory Process}

Following a long reflexive undertaking over several years, ${ }^{3}$ Gouttenoire et al. (2014) proposed an analysis framework to facilitate exchanges between researchers around participatory research projects. It qualifies participation processes.

The analysis framework is structured into six items. Researchers' and actors' expectations compared to what is achieved together are a result of the production of knowledge and actionable knowledge, the exchange of information or discussion, and so on. It is necessary to have clarified this, so as not to confuse the objectives. The course of the interactions between researchers and actors is described in successive stages. Interactions include both periods of explicit joint participation (such as workshops or interviews), and the interactions that may take place upstream or downstream (for example, upstream to decide on the actors to invite, or downstream to recover the outputs of participatory processes). For each of these stages, the goals and the concrete facilitation mechanisms are specified. The characteristics of groups of participating actors demonstrate their diversity or homogeneity, whether intended or not. A crucial point is that of the actors' engagement: what are they engaging in by participating in the process, and to what extent are they engaged? In parallel but not identically, the role of actors and the mechanisms of researcher intervention are specified during each stage of interaction. The role of actors can be to provide information, to give their opinion, or to co-construct or even drive forward the action; that of researchers can be to facilitate participation, formalise productions, or even co-construct. This distinction between researchers and actors in turn links back to the expectations of each of them, and can be subject to different mechanisms, depending on the stage.

\section{What About the TATA-BOX Participatory Process?}

If we apply this framework to TATA-BOX, we can say that, on the one hand, part of the framework is still relevant as a framework for analysing TATA-BOX; and on the other hand, that TATA-BOX is effective from the perspective of this framework and enriches it. Below we justify these different points.

In TATA-BOX, researchers' expectations are clear: their intention is to support the TAET. The conceptual frameworks to achieve this are varied, and go beyond the MLP approach to transitions (Geels 2004). An ad hoc framework is built for a complex system considered dynamically in its full complexity (Therond et al. 2017), at the articulation between socio-technical systems and socio-ecological systems, and aimed at achieving the autonomy of farming systems (Madelrieux et al. 2017).

The actors' expectations are vaguer and are revealed by their assessments of the operationality of the process: they find the ideas to be unoriginal and difficult to implement. Lastly, we may wonder how the researchers manage to enrol them. This raises the question of the actors' engagement. Are they there to please the researchers, or are they seeking solutions for their future? Are they aware that they are experimenting with new paths, or do they just feel good about contributing to a

\footnotetext{
${ }^{3}$ Originally a researcher workshop on participation, organised in 2017 by the INRA-SAD.
} 
trendy subject? The ties existing between researchers and actors upstream of the process are also a representation to discuss further.

TATA-BOX gives a remarkable representation of the course of the interactions between researchers and actors, whether through the conceptual diagram of the methodological itinerary, from the analysis of the system to governance mechanisms, including prospective design and analysis, or the variety of illustrations of the design and redesign of an interactive and didactic process. The small guide to support the collective design of an AETS (Audouin et al. 2018a) is the most palpable intermediary object, and can in itself be a model to follow for the quality of representations and the quantity of information transmitted.

The features of the actors participating (or not) are equipped by original representations, whether through the positioning of the actors interviewed, the analysis of their central or peripheral role in the system of interactions, their cognitive maps, or their illustrated pathways. These tools can be generalised to other situations in other processes. They can be a source of inspiration.

Yet the actors play a somewhat silent role. If they are key actors in the system, are they explicitly called upon as such, and do they consciously contribute to this intermediary role?

Conversely, do all researchers have the same activity in the process, and do they intervene homogenously? This is apparent in the articles that they produce: one theorises the process, another evaluates it; one produces useful knowledge, another uses it; one is reflexive, another is visionary. Some are both simultaneously. While the collective learning process is examined critically with respect to the actors, it would also be useful to question it with respect to the researchers, or even the students involved in the action-research-training devices (Lardon 2009), supposing the experiment renews not only knowledge but also capabilities (Lardon et al. 2015).

More recently, the researcher workshop entitled "Science and participatory research: practices and epistemology" (Les sciences et recherches participatives: pratiques et épistémologie,${ }^{4}$ organised by FormaSciences, bolstered the relevance of questions around the engagement of actors and researchers. This included questions that explain the reasons for the failure of such processes (Gonzalo-Turpin et al. 2009), as well as those on the place of researchers in processes, as experts contributing scientific knowledge or as facilitators of interactions between actors, through their active role in the formalisation and transmission of knowledge, or by establishing distance to guarantee the neutrality of the device. While participatory research processes are widespread at the INRA, they do not have the same assumptions or the same mechanisms. Diversity is a must.

\footnotetext{
${ }^{4}$ This research workshop took place in Pont à Mousson on 9-13 October 2017. Bringing together around 30 researchers, it aimed at understanding the diversity of types of participatory projects at the INRA; sharing the experiences, tools, and methods used as a part of participatory processes; and situating participatory projects within an epistemological and ethical framework.
} 


\section{Governance of the Transition Process}

Governance was addressed in two different ways by a group of researchers involved in the DATAR's research in 2008-2010, evaluating "rural excellence hubs" (PER, pôles d'excellence rurale $)^{5}$ (Lardon et al. 2016). The first consisted in analysing the socio-spatial configurations making up territories engaged in PER projects. The second came into play through the actors-stakeholders involved in creating and facilitating PER to analyse development pathways.

PER had to constitute spaces for discussing the project and defining the boundaries of cooperation. By putting emphasis on public-private partnerships and support for the initiatives of small project drivers, the device was primarily intended to encourage joint territorial governance practices. In the end, 670 PER were certified between 2006 and 2009.

The analysis framework for socio-spatial configurations reveals the development potential of PER projects. It specifies the dynamics of social relations necessary to construct collective action (Angeon et al. 2006), and sheds light on their territorial anchoring and the spatial models resulting from territorial dynamics (Lardon and Piveteau 2005). Socio-spatial configurations are characterised by the spatial distribution - whether concentrated or diffused - of actors and actions within the project territory, and the ties - whether established or not - with external actors. These are cross-compared with the way that the different types of actors (institutional, consular, association, corporate, or research actors) get involved in building the PER project. The models created in this way demonstrate the contribution of actions to the territorial project and reveal the synergies at play between actors and their room to manoeuvre in order to execute their project.

The dynamics and changes marking the development pathways of PER (Milian and Bacconnier-Baylet 2014) can be interpreted through the continuities, shifts, and even discontinuities that take place in the (re)definition of the resources on which a territorial system bases its development (activation and valorisation of these resources), as well as its organisational and structural reorganisation. The idea is to retrace the evolution of the local system's capacity for initiative, and to reconstruct the way in which it became involved in "innovative" processes, thus contributing to the construction or consolidation of territorial governance. This leads to a study of the facilitation and decision-making system at work around the territory's development pathway, and the innovations and compositions that it promoted or catalysed.

Cross-analysing these two approaches highlights possible levers for action for territorial development. Two key elements must be noted with respect to territorial governance. The first is the need to facilitate places and moments of dialogue between the different actors involved, with a view to co-constructing development processes. The second is to ensure support for intermediary actors that were not necessarily foreseen at the outset, but which emerged during the course of the process.

\footnotetext{
${ }^{5}$ http://www.datar.gouv.fr/programme-de-recherche-evaluative-sur-les-poles-dexcellencerurale-2009
} 


\section{Is Reflection on Territorial Governance Projects Applicable to TATA-BOX?}

TATA-BOX uses pathways to represent actors' logics and to line these up with transition phases. It analyses social configurations by representing technical, economic, and material exchange networks between actors. However, spatial configurations are not taken into consideration. At the most, the spatial dimension serves to qualify the biotechnical and decision-making dimensions through its anchoring, dependence, and imprint (cf. chapter "An Integrated Approach to Livestock Farming Systems' Autonomy in Designing and Managing Agroecological Transition at the Farm and Territorial Levels"). The map representation is first used to locate the groups involved in the process in terms of types of production system (cf. chapter "An Integrated Approach to Livestock Farming Systems' Autonomy in Designing and Managing Agroecological Transition at the Farm and Territorial Levels"), and then later used to locate the fields of study in Midi-Pyrénées in terms of types of production system (cf. chapter "Participatory Methodology for Designing an Agroecological Transition at Local Level"). Moreover, while the shared vision of local agriculture by 2025 for the territory of Midi Quercy is a detailed representation of 65 targets, at times localised, symbolised within the three concentric circles of the farm, the territory, and the country, none of these analyse either the specific spatial configurations or interrelations between spatial scales. Would this not therefore constitute a loss of development potential for territories, through the deprivation of tools for analysing socio-spatial configurations (Lardon 2015)?

TATA-BOX stresses the diversity of the actors already involved and to involve in order to make it possible to steer action. From an analytical point of view, this consists in identifying the boundaries of the system and the stakes of actors-stakeholders. From an operational point of view, governance relates to the mechanisms that these actors use to make the system evolve towards the desired state. These boundaries are within a space of overlap between the socio-technical and the socio-ecological system. Issues surround the public and private coordination of goods. In a guide on implementing governance to support the sustainable development of territories, Hélène Rey-Valette et al. (2011) proposes a tool to strengthen territorial governance engineering. Its key features are: sharing knowledge around the topic of territorial governance and complementary forms of partnership; the need to make scales of observation evolve along the way; and partnerships, due to both the multi-level nature of the processes and the complexity of contexts. These key features convey and compare the diversity of possible forms for implementing this territorial governance. The operationalisation of territorial governments is based on five properties: participation; the organisation of steering; interdisciplinarity; assessment; and continuous improvement. Participation, the organisation of steering, and assessment position the framework of devices and actions carried out. Interdisciplinarity and continuous improvement are more general goals that raise questions in order to integrate these principles into procedures. They result in adaptive processes involving the consideration of the long term and requiring collective learning processes in view of sustainable development (Valette et al. 2008). These proposals go further than what is done in the TATA-BOX process, even if the same goals have been defined. 


\section{Collective Action for Territorial Development}

Amblard et al. (2018) provide a summary of the contributions of a territorial approach to collective action, in terms of the production of scientific knowledge and knowledge for action. It is based on the authors' analysis of work carried out by researcher members of UMR Territoires, and is compared to a review of national and international literature. The authors' analysis identifies three lines of questioning that structure the contributions of research on collective action in relation to the territory:

1. To what extent do territories determine the development of collective actions? What is the respective contribution of territorial and supra-territorial factors in the development of collective action? The strategies of the actors involved as well as the procedures and governance modes in place are often central in the analysis of the role of collective action. Seen on the territorial scale, these analyses shine light on the territorial factors determining the development of collective action. Research also highlights the role of factors related to socio-economic and political contexts, beyond the borders of the territory, as well as the interactions between the characteristics of the territory and contextual factors.

2. Collective actions take on different forms in territories. How are these forms related to territorial particularities? How is it possible to build common ground between the actors involved? What is the contribution of the different actors to the collective dynamic? The apparent diversity of forms adopted by collective action in territories raises the question of the logics underpinning these organisational configurations in relation to the issues of each territory. Defining the boundaries of the groups involved leads to questions on the power relations or construction of common worlds between participants in the action on the territorial scale. The analysis of collective action in territories reveals the specific role played by certain actors in an intermediary situation within the groups in question.

3. Lastly and reciprocally, how does collective action contribute to territorial development, generate new resources, and make new territories emerge? The question of the impact of collective actions on the territory constitutes a major component of research on the subject. Some publications analyse the effects of these actions on the economic development of territories; others emphasise their indirect effects on the transformations of territories, through the creation or activation of new resources. The entanglement of collective actions, which can either compete with or complement one another, influences their capacity to transform territories.

Two conceptual frameworks were put to the test (Amblard et al. 2018). That of socio-ecological systems (Ostrom 2009) aims at broadening the institutional approach to collective action so that it takes into consideration the characteristics of the ecological system considered, along with interactions with social systems. It simultaneously allows us to understand the role of territorial factors, modes of 
governance, and contextual factors. The processual approach (Mendez et al. 2010) introduces the possibility of identifying the territorial resources activated over time, and thus aims at understanding the combination of the dynamics at the bases of processes. But what tools support collective action in territories and what is their heuristic scope?

We have answered this question, such as through the example of the "territory game", which is an expression game that promotes the construction of a shared viewpoint of the territory (Lardon 2013). It constitutes an instance of interventional research, in the sense of Hatchuel (2001), providing its capacity for establishing distance and formalising results. The production of knowledge for action is carried out as a part of an iterative process, in which the knowledge of actors and of researchers is shared (Béguin 2007) and appropriated. A collaborative design process takes place (Brassac 2004), in which each person finds his or her place and makes use of the collective production. In this sense, the game establishes dialogue between territorial actors (elected officials, inhabitants, professionals, etc.) and researchers around different intermediary objects (Vinck 2009), such as the maps produced during the process of knowledge production and the valorisation of experiences. These outputs are analysed from the angle of the concerns that they address (Lardon et al. 2016).

\section{What Is the Case for TATA-BOX?}

As indicated in chapter "A Plurality of Viewpoints Regarding the Uncertainties of the Agroecological Transition" on the uncertainty of the AET, "research on the analysis and support of the AET has mainly sought to describe change processes. However, it is necessary to consider the obstacles and levers involved in these changes on different organisational levels (production systems, supply chains, the territory, etc.), as well as the trajectories and pathways of the transition, and in doing so, to consider methodologies for supporting actors in this transition."

Chapter "Participatory Methodology for Designing an Agroecological Transition at Local Level" presents the participatory methodology by highlighting transition trajectories and pathways. This could be the case in chapter "Information and Communication Technology (ICT) and the Agroecological Transition", which establishes a platform based on information and communication technologies, if it were to go beyond the stated challenges.

When considering this scientific publication, a slight sense of dissatisfaction remains in terms of the contribution to participatory research for action, even though quite the opposite is true when we look at the short companion guide (Audouin et al. 2018a).

\section{TATA-BOX, a Tool for Action and a Participatory Research Model}

Based on my interdisciplinary study of the TATA-BOX project, I have three comments and three proposals. 
First, the project's scientific outputs are remarkable, with more specifically the formalisation of conceptual frameworks upstream and along the way, the reflexive feedback and assessment downstream, the diversity of disciplinary viewpoints provided, and the involvement of researchers in the 40 or so workshops and sessions over the course of the 4 years of the process. The AET is modelled; the practices of farmers and other actors are analysed; the governance and management of uncertainty are discussed. However, even though a diversity of viewpoints is expressed, the logic of reasoning is justified, and the invention of new reference frameworks is presented, this is in relation to the scientific component. Ultimately, there is no space where actors are able to appear as knowledge producers, whether actionable knowledge or not. Actors are similarly categorised by the researchers into their livestock farming typologies (such as in chapter "An Integrated Approach to Livestock Farming Systems' Autonomy in Designing and Managing Agroecological Transition at the Farm and Territorial Levels") or based on their exchange networks (in chapter "The Key Role of Actors in the Agroecological Transition of Farmers: A CaseStudy in the Tarn-Aveyron Basin"). Alternatively, their behaviours or exchanges are evaluated by the researchers (such as in chapter "Towards a Reflective Approach to Research Project Management").

One suggestion would be increasingly to hybridise expert knowledge and situated knowledge, because, as Luc Gwiazdzinski (2016) put it: "The territory is at the heart of these recompositions and hybridisations that engage the sensible and the ephemeral. New figures emerge, new scenes, and new ways of cooperating appear on different scales and according to plural mechanisms. To address issues, crossed actions take place; hybridisations become possible".

The operational production of the process is promising: a diversity of tools was created, whether to represent action logics, trajectories, networks of actors, strategic pillars, transition pathways, levers for action, or other. These tools present the complexity of the systems studied without reducing it, not to facilitate appropriation but to multiply forms, to better transmit them. There is however no analysis of what these tools produce beyond the words of actors around individual contributions. What of the knowledge produced on dynamics, the collective dimension, and the development of territories?

One proposal to increase actors' ability to master the processes involving them (Deffontaines et al. 2001) would be to deepen the analysis of these intermediary objects that constitute boundaries (Vinck 2009) between researchers and actors. They are integrative objects (in the sense of Schmid and Hatchuel 2014) that articulate portions of knowledge and take on meaning in the future. The territory is the place of the interconnection between public policies and local initiatives, between the past and the future, between activities and uses. All of this must be taken into consideration in a systemic and operational approach.

Reflexivity is at the heart of the device; it is manifest in the feedback on the device as well as in the anticipation of future tools, made possible by information and communication technologies, and in the valorisation of past knowledge, which becomes a resource in the present. While participatory processes are adaptive by nature, in order to address the needs expressed in the field, they are also performa- 
tive, because an objective presides over the performance, the process over the results, and the meaning over achievements.

One proposal to have a more detached view of experiments of this type would be to ensure their traceability, to retain records of them, and to send the knowledge acquired and capabilities developed to be mirrored. The territories will not do so alone; they will do so in relation to neighbouring territories, integrating the local and the global. While Martin Vanier (2008) announced this over a decade ago, when it comes to multi-scale territorial recompositions, the urgency of inter-territoriality is currently taking on its full meaning. The territorial project remains applicable, but ties with neighbouring territories, involvement in broader scales, and acknowledgement of territorial differences are all interactions that should be taken into account, in order to open up a territory to the world instead of solidifying it within its boundaries.

Hybridisation, integration, and inter-territorialisation are conditions for inventing the territories of the future ${ }^{6}$ and for taking charge of the territorial transitions underway (Lardon 2017), whether agroecological or not. This is a paradigm shift!

Let's draw inspiration from Albert Jacquard's (1991) Voici le temps du monde fini.

\section{References}

Amblard L, Berthomé GEK, Houdart M, Lardon S (2018) L'action collective dans les territoires. Questions structurantes et fronts de recherche. Géographie, économie, société 20:227-246. https://doi.org/10.3166/ges.20.2017.0032

Angeon V, Caron P, Lardon S (2006) Des liens sociaux à la construction d'un développement territorial durable: quel rôle de la proximité dans ce processus? Développement durable Territ. https://doi.org/10.4000/developpementdurable.2851

Audouin E, Bergez JE, Choisis JP et al (2018a) Petit guide de l'accompagnement à la conception collective d' une transition agroécologique à l' échelle du territoire. Toulouse

Audouin E, Bergez JE, Therond O (2018b) TATA-BOX, Neuf métaphores des concepts clefs des démarches participatives pour la transition Agroécologique

Béguin P (2007) Innovation et cadre sociocognitif des interactions concepteurs-opérateurs: une approche développementale. Trav Hum 70:369. https://doi.org/10.3917/th.704.0369

Béguin P, Rabardel P (2000) Designing for instrument mediated activity. Scand J Inf Syst 12:173-190

Brassac C (2004) Action située et distribuée et analyse du discours: quelques interrogations. Cah Linguist française, Univ Genève 26:251-268

Brunet R (1986) La carte-modèle et les chorèmes. Mappemonde 4:2-6

Coquil X, Lusson JM, Beguin P, Dedieu B (2013) Itinéraires vers des systèmes autonomes et économes en intrants: motivations, transition, apprentissages. In: 20eme Rencontres Recherches Ruminants. France, Paris, pp 1-4

\footnotetext{
${ }^{6}$ This is the title of the research project PSDR INVENTER (https://www.psdr4-auvergne.fr/ PSDR-4/Les-4-projets/INVENTER), which aims at formalising the dynamics of the evolution of rural and metropolitan territories, drawing support from food governance, and designing the support for change.
} 
Deffontaines JP, Marcelpoil E, Moquay P (2001) Le développement territorial: une diversité d'interprétations. In: Lardon S, Maurel P, Piveteau V (eds) Représentations spatiales et développement territorial. Bilan d'expériences et perspectives méthodologiques. Hermès, Paris, pp $39-56$

Duru M, Therond O, Fares M (2015) Designing agroecological transitions; a review. Agron Sustain Dev 35:1237-1257. https://doi.org/10.1007/s13593-015-0318-x

Elzen B, Geels FW, Green K (2004) System innovation and the transition to sustainability: theory, evidence and policy. Edward Elgar Publishing, Cheltenham

Geels FW (2004) From sectoral systems of innovation to socio-technical systems. Res Policy 33:897-920. https://doi.org/10.1016/j.respol.2004.01.015

Gonzalo-Turpin H, Couix N, Hazard L (2009) Rethinking partenerships with the aim of producing knowledge with pratical relevance: a case study in the field of ecological restoration. Ecol Soc 13:53

Gouttenoire L, Taverne M, Cournut S et al (2014) Faciliter les échanges entre chercheurs sur les projets de recherche participative: proposition d'une grille d'analyse. Cah Agric 23:205-212. https://doi.org/10.1684/agr.2014.0703

Gwiazdzinski L (2016) L'hybridation des mondes. Territoires et organisations à l'épreuve de l'hybridation. L'innovation autrement, Elya Editions, France

Hatchuel A (2001) Quel horizon pour les sciences de gestion? Vers une théorie de l'action collective. In: David A, Hatchuel A, Laufer R (eds) Les nouvelles fondations des sciences de gestion. Vuibert, Paris, pp 21-45

Jacquart A (1991) Voici le temps du monde fini. Seuil, Paris

Lardon S (2009.) Former des ingénieurs-projets en développement territorial) Un itinéraire méthodologique pour faciliter la participation des acteurs. In: Béguin P, Cerf $\mathrm{M}$ (eds) Dynamiques des savoirs, dynamiques des changements. Octarés, Toulouse, pp 209-227

Lardon S (2013) Developing a territorial project. The «territory game », a coordination tool for local stakeholders. FaçSADe, Res Results 38:4

Lardon S (2015) L'agriculture comme potentiel de développement des territoires périurbains. Analyse par les configurations socio-spatiales. Articulo. https://doi.org/10.4000/articulo.2673

Lardon S (2017) L'aménagement du territoire au prisme des transitions territoriales: un triple processus à l'œuvre. Pouvoirs Locaux 110:81-86

Lardon S, Piveteau V (2005) Méthodologie de diagnostic pour le projet de territoire: une approche par les modèles spatiaux. Géocarrefour 80:75-90. https://doi.org/10.4000/geocarrefour.980

Lardon S, Milian J, Loudiyi S et al (2014) Du potentiel à l'action: la gouvernance territoriale des pôles d'excellence rurale. Norois:69-81. https://doi.org/10.4000/norois.5380

Lardon S, Albaladejo C, Allain S et al (2015) Dispositifs de Recherche-Formation-Action pour et sur le développement agricole et territorial. In: Torre A, Vollet D (eds) Partenariats pour le développement territorial. QUAE, Versailles, pp 47-57

Lardon S, Marracini E, Filippini R et al (2016) Prospective participative pour la zone urbaine de Pise (Italie). L'eau et l'alimentation comme enjeux de développement territorial. Cah Geogr Que 20:265-286

Legay J (1986) Méthodes et modèles dans l'étude des systèmes complexes. Cah la Rech 11:1-6

Lemoigne JL (1990) La modélisation des systèmes complexes. Dunod, Paris

Madelrieux S, Buclet N, Lescoat P, Moraine M (2017) Écologie et économie des interactions entre filières agricoles et territoire : quels concepts et cadre d'analyse?

Mendez A, Bidart C, Brochier D et al (2010) Processus: concepts et méthode pour l'analyse temporelle en sciences sociales. Academia-Bruylant, Paris

Milian J, Bacconnier-Baylet S (2014) Requalifier les territoires de l'action locale. Territ en Mouv:54-67. https://doi.org/10.4000/tem.2399

Ostrom E (2009) A general framework for analyzing sustainability of social-ecological systems. Science 325:419-422. https://doi.org/10.1126/science.1172133

Rey-Valette H, Pinto M, Maurel P et al (2011) Guide pour la mise en œuvre de la gouvernance en appui au développement durable des territoires 
Schmid AF, Hatchuel A (2014) On generic epistemology. Angelaki 19:131-144. https://doi.org/1 0.1080/0969725X.2014.950868

Thénard V, Jost J, Choisis JP, Magne MA (2014) Applying agroecological principles to redesign and to assess dairy sheep farming systems. In: Options Méditerranéennes. Série A. ICAMAS/ CIHEAM, Paris, pp 785-789

Therond O, Duru M, Roger-Estrade J, Richard G (2017) A new analytical framework of farming system and agriculture model diversities. A review. Agron Sustain Dev 37:21. https://doi. org/10.1007/s13593-017-0429-7

Thévenot L, Moody M, Lafaye C (2000) Forms of valuing nature: arguments and modes of justification in French and American environmental disputes. In: Lamont M, Thévenot L (eds) Rethinking comparative cultural sociology: repertoires of evaluation in France and the United States. Cambridge University Press, Cambridge, pp 229-272

Valette HR, Lardon S, Chia E (2008) Editorial: governance- institutional and learning plans facilitating the appropriation of sustainable development. Int J Sustain Dev 11:101. https://doi. org/10.1504/IJSD.2008.026506

Vanier M (2008) Le pouvoir des territoires. Essai sur l'interterritorialité, Paris

Vinck D (2009) De l'objet intermédiaire à l'objet-frontière, Vers la prise en compte du travail d'équipement. Rev d'anthropologie des connaissances 3:51-72

Open Access This chapter is licensed under the terms of the Creative Commons Attribution 4.0 International License (http://creativecommons.org/licenses/by/4.0/), which permits use, sharing, adaptation, distribution and reproduction in any medium or format, as long as you give appropriate credit to the original author(s) and the source, provide a link to the Creative Commons licence and indicate if changes were made.

The images or other third party material in this chapter are included in the chapter's Creative Commons licence, unless indicated otherwise in a credit line to the material. If material is not included in the chapter's Creative Commons licence and your intended use is not permitted by statutory regulation or exceeds the permitted use, you will need to obtain permission directly from the copyright holder.

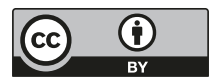

